\title{
Developmental and Histological Studies of Fungiform Papillae in Fetal Human Tongue
}

\author{
Lotfy Sayed *, Atef Ibrahim *, Esam Abdelhady *, Hosam El-Din \\ Hussin * and Ghassan Ahmed ** \\ *Departments of Anatomy and Histology-Faculty of Medicine Al Azhar University \\ ** Catalyst, USAID (United States Agency for International Development)
}

\begin{abstract}
This study was designed to evaluate the histological development of fungiform papillae of human tongue during the prenatal period.

Lateral Sagittal sections were taken at autopsy from the anterior two-third of 18 aborted fetuses of $8,10,12$, and 20 weeks of gestations and 2 stillborn infants at 40 weeks of gestation. Twenty specimens were prepared in paraffin and stained for histological study. The gestational ages were calculated after measuring the Crown Rump Length [C.R.L.]. It was found that the first appearance of fungiform papillae was nearly about the $10^{\text {th }}$ week of gestation, before the appearance of filiform papillae, most of the developed fungiform papillae were cylindrical in shaped with appearance of nerve plexus, at $12^{\text {th }}$ week they reached mushroom shaped with narrow base and broad apex and became differentiated into primary and secondary papillae, also presumptive taste buds were noticed at this age in the form of multiple local thickening of papillary epithelium. At $20^{\text {th }}$ week of gestation the taste buds became more developed, the papillae appeared more vascular. At full term $\left(40^{\text {th }}\right.$ week) the fungi form papillae reached full maturity.

It is concluded that this study suggests that the development of fungi form papillae requires an epithelial and mesenchymal interaction during morphogenesis
\end{abstract}

\section{Introduction}

Microscopic studies have been made on the prenatal developing fungiform papillae and Innervations in human fetal tongue. Their relation to vascularization and Pansky (1982) explained that the development of the tongue from the branchial arches and explained its nerve supply. The sensory nerve supply to the mucosa of almost the entire anterior two thirds of the tongue was from the lingual branch of the mandibular division of the trigeminal nerve (the nerve of the first branchial arch). Although the facial nerve was the nerve of the second branchial arch, its chorda tympani branch supplied the anterior two thirds of the tongue except for the vallate papillae.

Moore (1982) stated that around the end of the fourth week, a median somewhat triangular elevation appeared in the floor of the pharynx just rostral to foramen caecum. This elevation, the median tongue bud (tuberculum impar) gave the first indication of tongue development. Soon, two oval distal tongue buds (lateral lingual swellings) developed on each side of the median tongue bud. The two lateral elevations rapidly increased in size, merged with each other and overgrew the median tongue bud. The merged distal buds formed the anterior two thirds or oral part of the tongue. The median tongue bud formed no recognizable portion of the adult tongue.

Romanes (1993) stated that the branchial arch mesenchyme formed the connective tissue, the lymphatic tissue and blood vessels of the tongue and probably some of its muscle fibers. Most of the tongue musculature was derived from myoblasts that migrated from myotomes of the occipital somites.

McLachlan (1994) stated that tuberculum impar arose from the caudal end of the first branchial arch and the lateral lingual swellings resulted from proliferation of mesenchyme in the ventromedial parts of 
the first pair of branchial arch. Hence the mucous membrane of the anterior twothirds of the tongue arose from the first arch.

Williams et al, (1995) and Wheater et al, (1996) mentioned that the fungiform papillae were located mainly on the lingual margin also irregularly on the dorsum of the anterior two-thirds of the tongue, where they might occasionally be numerous. They differed from filiform papillae by their larger size; rounded shape and deep red color, each usually beard one or more taste buds on its apical surface.

Witt and Reuters (1997) mentioned that the papillae of the tongue appeared around the post ovulatory (the 8thweek of gestation). The vallate and the foliate papillae appeared first in close relationship to the terminal branches of the glosso pharyngeal nerve. The fungiform papillae appeared later near the termination of the chorda tympani nerve. All the previous papillae developed later taste buds. The filiform papillae developed later after the fungiform papillae. In contrast to the large and well documented informations on the morphology of the fungiform papillae in adult human, there is on sufficient reports concerning the development and differentiation of the human fungiform papillae.

The present study tries to offer more informations about the histogensis of the prenatal development of the fungiform and their relation to vascularization and innervations in human fetal tongue.

\section{Material and Methods}

Twenty human male and female fresh fetuses (prenatal age ranged from $8^{\text {th }}$ week to full term) were used in this study. The fetuses were obtained from Al-Azhar university hospitals. The CRL of each fetus was measured and then converted into weeks of menstrual prenatal ages in accordance with accurate tables of Steeper (1920) and Longman (1975). Two or three specimens represented each week of pregnancy, especially at the early prenatal ages.

The developing tongues were obtained from the fetuses and examined macroscopically to exclude any anomalies or pathological lesions. Specimens were taken from the anterior two-thirds of the tongues. The collected specimens were fixed in $10 \%$ formal saline solution. Then dehydrated, cleared in benzene, embedded in paraffin and cut sagittal 6um thick serial sections. Lateral sagittal sections were stained with haematoxylin and eosin to detect general histological structures of the fetal tongues (Drury and Wallington 1980).

Silver stain (Rashwan et al. 1976) was applied for demonstrating nerve fibers, plexuses and taste buds.

\section{Results}

The tongue of human fetus with CRL of 23 mm. ( 8 weeks)

Microscopic examination of lateral sagittal sections from the anterior twothirds of the tongue of human fetus with CRL of $23 \mathrm{~mm}$. (8 weeks) showed that the tongue was occupied mainly by a muscular mass that was formed of thin muscular bundles arranged into different directions. The muscular mass was covered on its dorsal surface by a thick stratified gummous epithelium which thrown into multiple epithelia projections to form the primitive papillae (Fig. 1. a). These papillae had solid epithelial cores. They were cylindrical in shape with both apices and bases had nearly the same width. Their apices were covered with a single layer of flat cells. No sign of keratinization was detected (Fig. 1. b.). The subepithelial connective tissue was forming the reticulum of primitive lamina propria, where smalldeveloped nervous elements could be detected. (Fig. 1. c).

The tongue of human fetus with CRL of 36 mm. (10 weeks)

Microscopic examination of lateral sagittal sections from the anterior twothirds of the tongue of human fetus with CRL of $36 \mathrm{~mm}$. (10 weeks) showed that the muscular mass was forming also the main bulk of the tongue but their muscular bundles were thick and apparently arranged into three different directions. Superior and inferior were longitudinal while the middle 


\section{Lotfy Sayed $\boldsymbol{e t}$ al}

one was transverse (Fig.2.a.). The dorsal surface of the muscular mass was covered with a stratified Squamous epithelium, which was excessively projected into different shaped lingual papillae. Most of them had narrow bases and broad apices. Each papilla showed a single connective tissue core that was not invaded with primitive capillaries. These papillae were representing the primary fungiform papillae (Fig. 2.b). The fungiform papilla was covered with thick but non-keratinized stratified squamous epithelium (Fig. 2.b). A well-developed dense nerve plexuses were detected in connective tissue core and the subepithelial layer of this papilla. Collections of dense nerve fibers were also noticed in some location in the epithelium of the papilla that represented the primitive taste bud (Fig.2.c).

The tongue of human fetus with CRL of 56 mm. (12 weeks)

Microscopic examination of lateral sagittal sections from the anterior twothirds of the tongue of a human fetus with CRL 56mm. (12weeks) showed that the surface epithelium was very thick and had thrown into highly packed fungiformpa pillae primitive filiform papillae with pointed apices and broad bases could be detected (Fig.3.a).The muscle bundles of the tongue appeared very thick and well developed especially the middle transverse layer (Fig.3.a). The papillary epithelium of fungiform papilla was very thick and showed packed cells occupied the apical part of the papillary epithelium, which represented the primitive taste bud (Fig.3.b). The connective tissue core of fungiform papilla was invaded by large blood vessel (Fig.3.b.).Also rich nerve plexuses could be detected in connective tissue core, lamina propria and also in the site of primitive taste bud at the apical epithelium where the cells became packed, enlarged and associated.(Fig.3.c).

The tongue of human fetus with CRL of $160 \mathrm{~mm}$. (20weeks).

Microscopic examination of lateral sagittal sections from the anterior twothirds of the tongue of a human fetus with
CRL of $160 \mathrm{~mm}$. (20 weeks) showed that the fungiform papillae had developed primary and secondary types and in between few filiform papillae (Fig.4.a). The papillary epithelium of secondary fungiform papilla was very thick. This epithelium showed inward growth, intra papillary extension inside the papillary core that converting the single connective tissue core into two cores and that fungiform papilla became secondary one. The connective tissue cores of primary and secondary fungiform papillae were rich in blood vessels (Fig.4.b). Most of the fungiform papillae were acquired the typical mushroom shaped with an apical taste bud .The taste bud was oval and occupied the whole thickness of apical epithelium of the papillae. The base of taste bud rest on connective tissue and its apex had a primitive gustatory pore called taste pit (Fig.4.c). The taste bud was presumptive, as it was not fully developed as it had a thick taste pore. The transitional cells at the periphery started to be detected. The cells inside the center of the taste bud although they could be differentiated into cells with dark nuclei and others with light nuclei but they were not fully arranged yet. The subepithelial nerve plexuses and nerve fibers could be detected and also taste bud on the apex of primary fungiform papilla (Fig.4.d).

\section{The tongue of human fetus at full term .}

Microscopic examination of lateral sagittal sections from anterior two-thirds of the tongue of human fetus at full term revealed that most of the fungiform papillae appeared well developed, muscle bundles of the tongue appeared thick and ran in different directions (longitudinal, transverse and vertical) (Fig. 5.a). The fungiform papillae enlarged with broad apex and narrow base and acquired more than one taste bud on its dorsal epithelial surface. Their cores were very vascular contained numerous blood vessels (Fig. 5.b). The taste buds appeared well developed as they had more differentiated cells and taste pore in the apex of the bud and became thin liable to rupture (Fig. 5.c). The cells of taste bud were differentiated into transitional cells 
which were located at the periphery and inside the taste bud, the cells had two types: (a) - dark supporting cells with dark oval nuclei and situated near the base of the bud. (b) - light gustatory cells were few in number situated near apex of the bud and had light cytoplasm and light oval nuclei. The nerve plexuses were detected at the base and the center of the papillary core (Fig. 5.d).

Plate 1: photomicrographs of lateral sagittal sections from the anterior two-thirds of the tongue of a human fetus with C.RL of 23 mm. (8 weeks)

Fig. 1-a: Showing multiple projections (J) arise from a thick stratified squamous epithelium (E) covers the dorsum of the tongue and Muscular mass $(\rightarrow)$, where its fibers are arranged into different directions. $\mathrm{H} \& \mathrm{E} \times 40$

Fig.1-b: Showing two epithelial projections that form the primitive Papillae (p.p). The papillae are cylindrical in shape with solid Core and covered with flat cells. H\&E x400 Fig. 1-c: Showing few nerve fibers in sub epithelial connective tissue. Silver stain $\mathrm{x} 200$

Plate 2: Photomicrographs of lateral sagittal sections from the anterior Two-thirds the tongue of a human fetus with CRL of 36 mm. (10 weeks).

Fig. 2-a: Notice that most of the dorsal epithelium became differentiated into primitive fungiform papillae (f.p) and few pointed filiform Papillae $(\rightarrow)$ the muscle fibers of the tongue appeared thick and arranged into superior and inferior longitudinal layers while the middle is transverse. H\&Ex40

Fig. 2-b: Showing thee primitive fungiform papillae of different degrees of development. The right one (1) is the less developed one as seen at its apex and base while the two left papillae are more developed (2) as seen from their wide apices and narrow bases. H\&E x400

Fig. 2-c: Showing the well-developed nerve plexus that invading the connective tissue core of the fungiform papilla. Notice also the dense collection of nerve fibers in the epithelium of its apex. Silver stain $\mathrm{x} 400$

Plate 3: Photomicrographs of lateral sagittal sections from the anterior Two-thirds of the tongue of a human fetus with CRL of 56 mm. (12 weeks)

Fig. 3-a: Showing the dorsal epithelium of the tongue which is formed mainly of the fungiform papillae (f.p) and few primitive filiform $(\rightarrow)$ The muscle fibers appeared thick and well developed especially the middle layer

$H \& E x 400$

Fig. 3-b: Showing the epithelium of fungiform papilla which became thick .Its cells became packed at the apex. The connective tissue core is invaded by blood vessels $(\rightarrow) \mathrm{H} \& \mathrm{Ex} 400$

Fig. 3-c: Showing a primary fungiform papilla with a primitive taste bud (T.B) occupies its apex. Notice the packed associate cells in the bud's epithelium. Notice also the rich nerve fibers in connective tissue core and Lamina propria. Silver stain X200

Plate 4: Photomicrographs of lateral sagittal sections from anterior Two-thirds of the tongue of a human fetus with C.R.L 160 mm. (20 weeks).

Fig.4-a: Showing well developed fungiform primary (1) and secondary (2) Types and few filiform papillae $H \& E$ x 40

Fig. 4-b: Showing secondary fungiform papilla with intra-papillary extension of dorsal epithelium. The connective tissue core is rich in blood vessels $(\rightarrow) H \& E$ x 400

Fig. 4-c: Showing fungiform papillae which acquired the mushroom shape. Notice the taste bud (T.B) which occupied the apical epithelium and rests on the connective tissue. H\&E X 200

Fig.4-d: Showing nerve fibers in connective tissue core, lamina Propria and taste bud on the dorsa surface of fungiform Papilla Silver stain x200

Plate 5: Photomicrographs of lateral sagittal sections from the anterior twothirds of the tongue of a human fetus at a full term

Fig.5-a: Showing well developed fungiform papillae and muscle bundles which run in different directions. $(\rightarrow)$ H\&E x 40

Fig.5-b: Showing a well-developed fungiform papilla with broad apex and narrow base, well-developed taste buds (T.B) on its dorsal epithelial surface. Notice the connective tissue core which became very vascular. $\quad H \& E x 400$ 


\section{Lotfy Sayed $\boldsymbol{e t}$ al}

Fig. 5-c: Showing two well-developed taste buds with different types of cells and taste pore is thin. $(\rightarrow) \mathrm{H} \& \mathrm{E} \times 800$

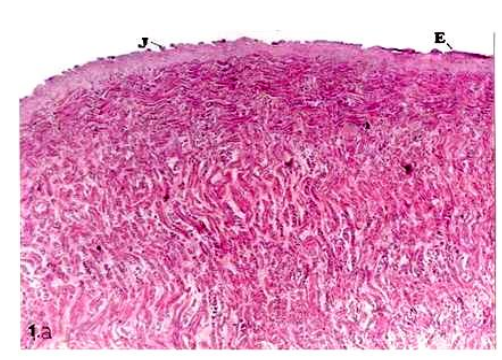

Fig. 1-a

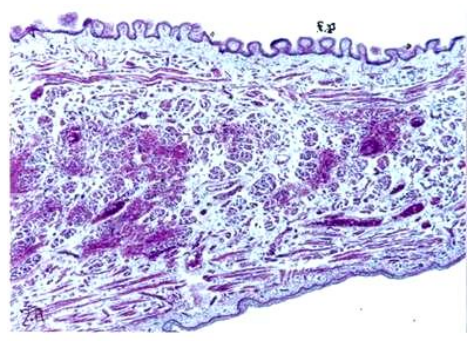

Fig.2-a

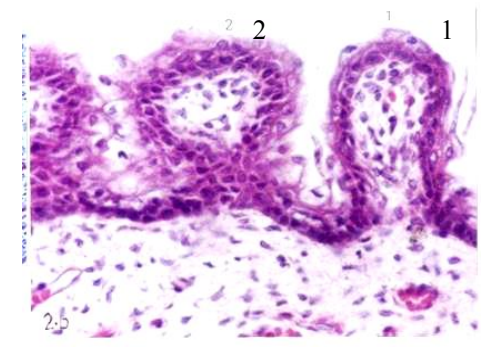

Fig. 2-b

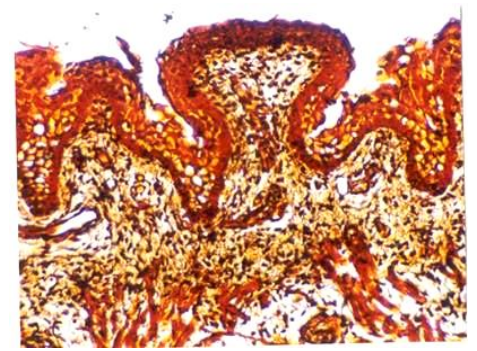

Fig. 2-c
Fig. 5-d: Showing nerve fibers and nerve plexus in taste bud papillary, core and lamina propria. Silver stain x2000

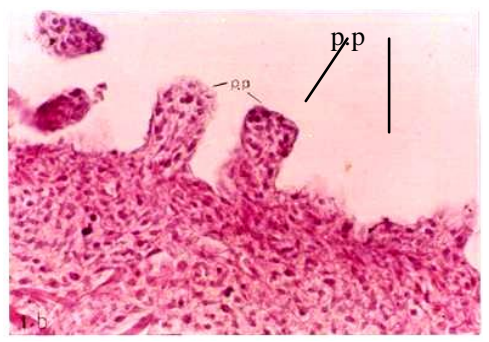

Fig. 1-b

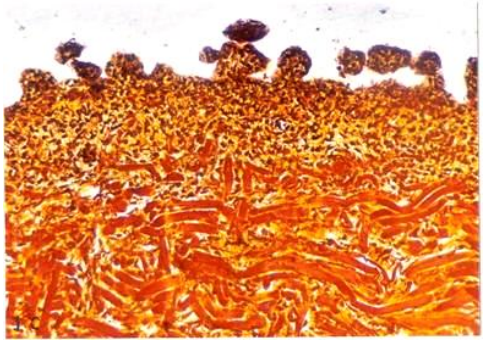

Fig. 1-c

Plate 1

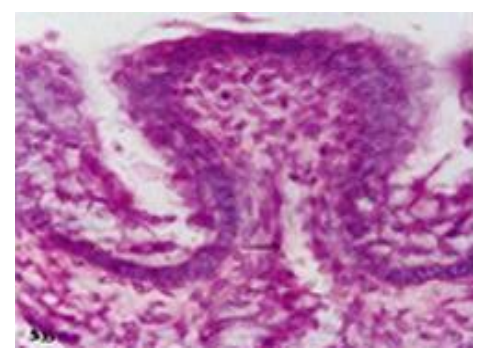

Fig. 3-b

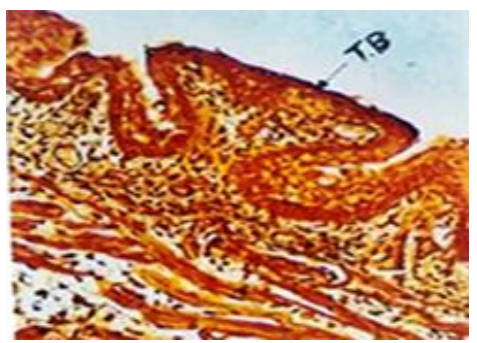

Fig. 3-c

$\underline{\text { Plate } 3}$ 


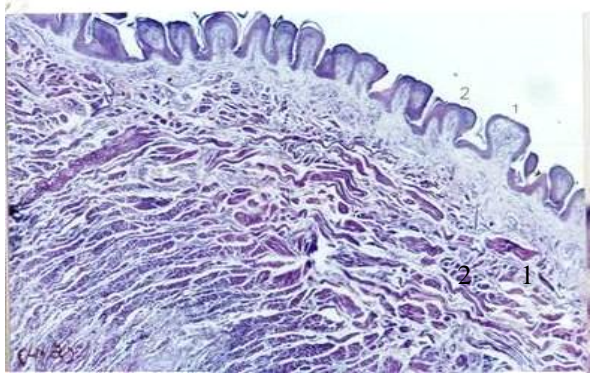

Fig. 4-a

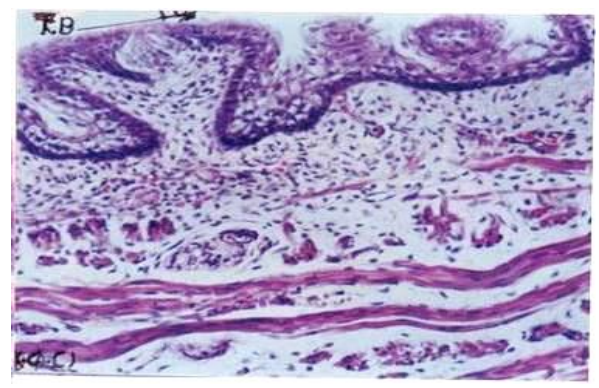

Fig. 4-b

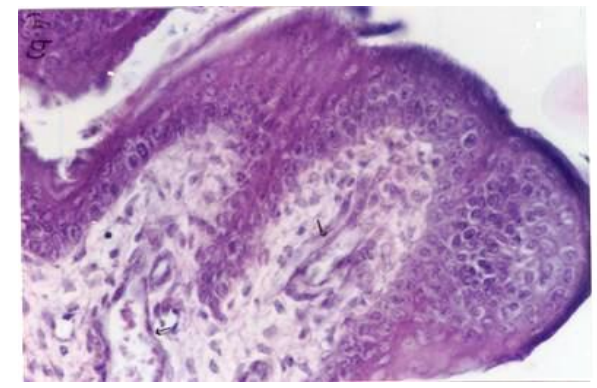

Fig. 4-c

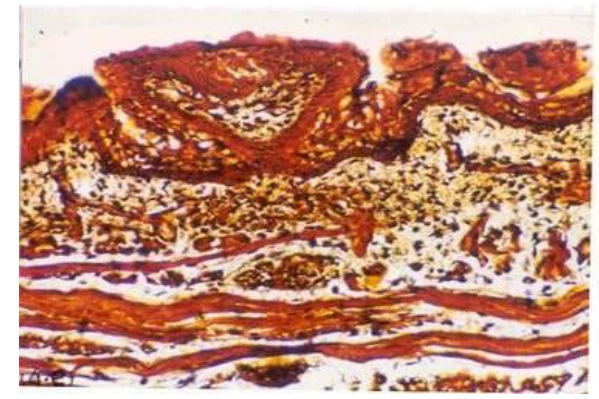

Fig.4-d

Plate 4

\section{Discussion}

Developmental histological studies of the structural elements of the anterior twothirds of the human tongue mainly the fungiform papillae were studied in this work. The histogensis of the prenatal developing fungiform papillae from the $8^{\text {th }}$ week of gestation till full term including

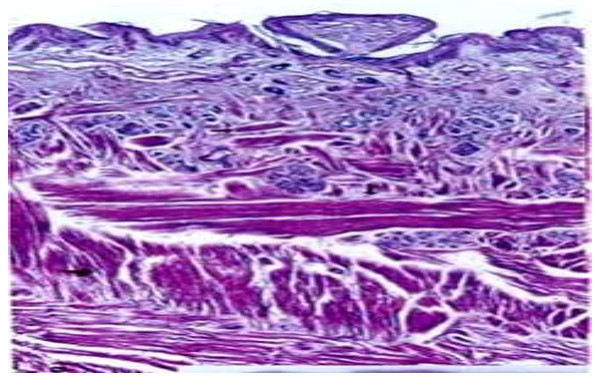

Fig.5-a

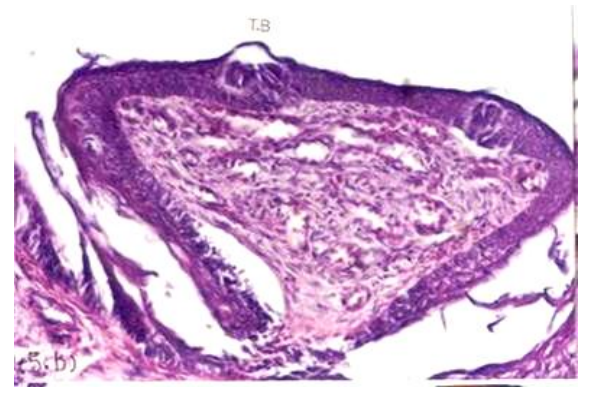

Fig. 5-b

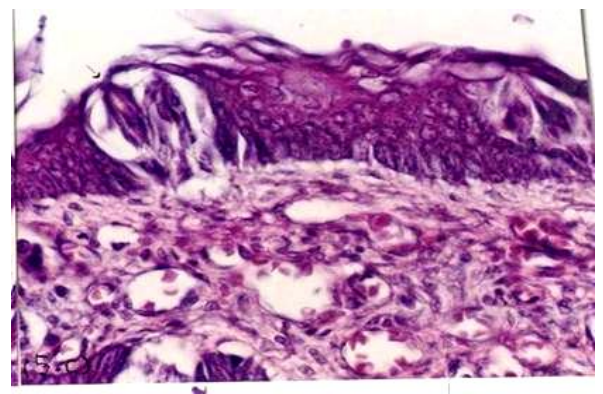

Fig. 5-c

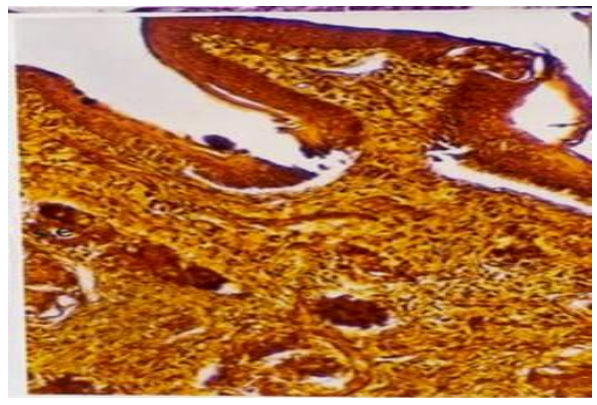

Fig. 5-d

Plate 5

their shape, epithelial covering, vascularization and innervations were studied in this work. In addition the development of taste buds in these papillae was also studied.

In the present work, at the $8^{\text {th }}$ week of gestation, the dorsal epithelium was formed of multiple epithelial projections which 


\section{Lotfy Sayed $\boldsymbol{e t}$ al}

were the primitive papillae covered by primitive stratified epithelium. At the $10^{\text {th }}$ week, the dorsal stratified squamous epithelium became excessively projected to form primary fungiform papillae. Most of these papillae were cylindrical in shape as they had the same width in bases and apices. At $12^{\text {th }}$ week of gestation the fungiform papillae became moderately developed acquired mushroom shape with narrow bases and broad apices. The filiform papillae started to appear at $12^{\text {th }}$ week of gestation. These results are in agreement with those of Arey (1974) who stated that fungiform papillae were developed before filiform papillae. The fungiform papillae tend to grow between 8 and 15 week of gestation and Steven and Lowe (1998) mentioned that the adult fungiform papillae had a mushroom shape. But the result of this work was not agreed with the results of Samar et al, (1990) who reported that the fungiform papillae being evident at $12^{\text {th }}$ week of gestation. In the present work, at the $10^{\text {th }}$ week of gestation the fungiform papillae were invaded by very few, small capillaries in their connective tissue core and increased in the later ages. At full term, these capillaries were forming large capillaries network.

These results confirmed the results of Fuents and Sanchiz (1992) who reported that there were very few capillaries making up the superficial vascular network under the epithelium of the fungiform papillae. The walls of these capillaries were progressively increased until a short time before birth. Makiyama et al, (1998) reported that in young rats the capillary network of the fungiform papillae had cylindrical form and later had a little fungus form.

In the present work, the muscular component of the tongue was different at $8^{\text {th }}$ week of gestation and became apparently arranged into definitive layers at the $10^{\text {th }}$ week of gestation. The result confirmed the results of Hamilton and Mossman (1972), Arey (1974), Moore (1982) and Sato and Sato (1992) as they noted that the tongue at $8^{\text {th }}$ week was elevated and assumed prominence through the differentiation of voluntary muscle internally which arranged into three layers.
In the present study at the $10^{\text {th }}$ week of gestation nerve plexuses were detected invading the connective tissue cores of the fungiform papillae. These plexuses were formed of bundles of nerve fibers. These nerve plexuses were progressively increased in size and distribution and at full term, they were detected at the bases and centers of connective tissue cores of the fungiform papillae.

In the present work the invasion of the fungiform papillae by the nerve plexuses were associated with the appearance of the presumptive taste buds and thus ensured the formative influence of the nerves to induce the development of taste buds. These results were in agreement with Arey (1974), Witt and Reuter (1998) and McDaniel (1999) as they reported that the functional relationship between the nerve and epithelium was more intimate that one might assume, since the nerve seemed to exert an organizing influence on the development of taste buds.

Witt and Reutter (1998) and McDanil (1999) reported that there was sub epithelial nerve plexuses with ganglion cells associated with taste buds. But the autonomic and somatosensory nerves seemed not to play a key role information and maintenance of early human taste buds.

In the present work, the taste buds appeared so primitive at $12^{\text {th }}$ week of gestation; they appeared as local epithelial thickening. At the $12^{\text {th }}$ week, they still primitive and occupied the apical part of the fungiform papillary epithelium. They were formed of closely associated cells which could be difficulty distinguished from the surrounding epithelium.

At $20^{\text {th }}$ week of gestation, it became presumptive and moderately developed taste buds were formed as they still had primitive taste pores and moderately developed cells.

At full term, the taste buds became well developed and occupied the whole epithelial thickness with well-developed taste pores and cells. These results confirmed the results of Arey (1974), Witt and Reutter (1997), and Iwasaki et al, (2001). As they reported that nerve fibers approached the basal membrane of the lingual epithelium around the $8^{\text {th }}$ week and 
invaded the basal membrane of papillae like structures at the $9^{\text {th }}$ week. Local thickening of the lingual epithelium presaged the first taste buds. The basal cells of such a thickened spot lengthened and extended toward the surface of the epithelium. This produced an epithelial cluster, which in later fetal months differentiated furthermore . Some of the elements specialized into slender taste cells which ending in hair like receptive tips, while others, became columnar supporting cells supposedly non sensory function. Reflex pathway between the taste buds and facial muscles were present by week 26 to 28 of gestation.

From the present study, it could be concluded that the fungiform papillae developed before filiform and reached the adult shape at $20^{\text {th }}$ week of prenatal life. There was also a vessel, nerve, taste organ relationship for development and growth of fungiform papillae.

\section{References}

1. Arey, L.B. (1974): "Developmental Anatomy". A Textbook and Laboratory Manual of Embryology. 7th edition. W.B. Saunders Company, Philadelphia and London. 232-243,523.

2. Drury, R.A.B. and Wallington, E.A. (1980): Carlton's Histological Technique. 5th edition. Oxford University press, Oxford, 137-145.

3. Fuentes, A. and Sanchiz .o. (1992): Microscopic innervations and vascular-rization of the tongue. Rev-stomatol-chir-Maxillofac. 93 (4): 278-284.

4. Hamilton, W.J. and Mossman, H.W. (1972): "Human Embryology". Prenatal development of form and function. 4th edition. The Macmillan press LTD., Cambridge, Huffer. 298-306.

5. Iwasaki SI, Asami T, Kageyama I. (2001): Ultra structural study of the precursor to fungiform papillae prior to the arrival of sensory nerves in the fetal rat. J Morphol. Dec;250(3):225-35

6. Longman, J. (1975): "Medical Embryology". 3rd edition. Williams \& Wilkins, Baltimore, p. 82.

7. Makiyama, M.C.: Watanabe, I.S.; Mizusakai, C.I. And Junior, K.B.(1998): Three dimensional angio architecture of tongue corrosion casts from normal young rats. Anat-Anz. 180(4): 327-330.

8. McDaniel, R.K. (1999): Sub epithelial nerve plexus (with ganglion cells) associated with taste buds. Oral Surg. Oral Mad.Oral Pathol. Oral Radiol. Endod.87 (5): 605-609.

9. Mc Lachlan, J. (1994): "Medical Embryology ". 1st edition. Addison Wesley Publishing Company. Wokingham, England. 236-237.

10. Moore K. (1982): "The developing of human clinically oriented embryology." $\quad 3^{\text {rd }}$-edition. W.B. Saunders Company, Phila-delphia, London, Toronto, Mexico City, Rio de Janeiro, Sydney, Tokyo. 195214.

11. Pansky, B. (1982): "Review of Medical Embryology." 1st edition. Macmillan Publishing Co., Inc. New York, Toronto, London. 138139.

12. Rashwan, S; Badawy, Y.H. and Elanani, E. (1976): A modification of silver impreg-nation methods of nervous tissues in paraffin sections. Al-Azhar Med.J.5 (2): 47-50.

13. Romanes, G.J. (1993): Cunnigham's Manual of Practical Anatomy. Volume 3: Head and neck and brain. Oxford University Press-Oxford, New York. 166-171, 301-304.

14.Samar, M.E.; Ferraris, M.E.; Avila, R.E., Defabro, S.P. and Ferraris, R.(1990): Human lingual organogenesis: Histoche-mical and Ultra structural aspects. An-FacOdontol. 26:5-19.

15. Sato, M. and Sato, T. (1992): Fine structure of developed human tongue muscle. Okaji-mas- FoliaAnat-JPN, 69 (2-3): 115-130.

16. Stevens, A. and Lowe, J.S. (1998): "Human Histology" 2nd edition, London, Baltimore, New York, Philadelphia, Toronto, Wiesbaden. 178-181, 178-181.

17. Steeper, G.L. (1920): Weight, sitting, height, head size, foot length and menstrual age of the human embryo. Contrib Embryol. 11: 143-170.

18. Wheater, P.R.; Burkitt, H.G. and Daniels, V.G.(1996): Wheater's functional Histology. 3rd edition. 


\section{Lotfy Sayed $\boldsymbol{e t}$ al}

Churchill Livingstone. Edinburgh, London. Madrid, Melbourne, New York and Tokyo. 242-245.

19. Williams, P.L.; Bannister, L.H.; Berry, M.M.; Collins, P.; Dyson, M; Dussek, J.E. and Ferguson, M.W. (1995): "Gray's Anatomy". 38th edition. Churchill Livingstone, New York, London, Edinburgh. 175-177; 1312-1314, 1721-1724.
20. Witt, M. and Reutter, K. (1997): "Scanning electron microscopical studies of developing gustatory papillae in humans. Chem. Senses, 22(6): 601-612.

21. Witt, M. and Reutter, K. (1998): Innervations of developing human taste buds. An immunohistochemical study. Histochem Cell Bid. 109 (3): 281291.

\section{دراسات هستولوجية لنمو الحـلمات الفطرية فى لسان الإنسان فى فترة مـا قبيل الولادة}

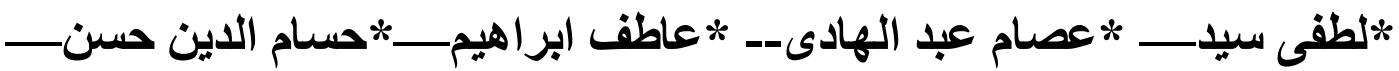

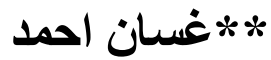

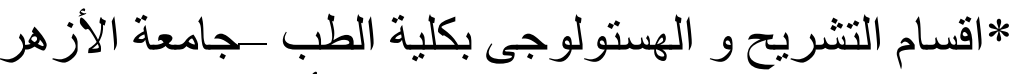
** كتاليست / هيئة المعونة الأمريكية

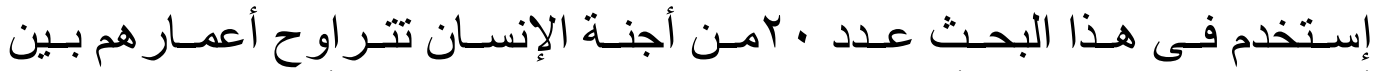

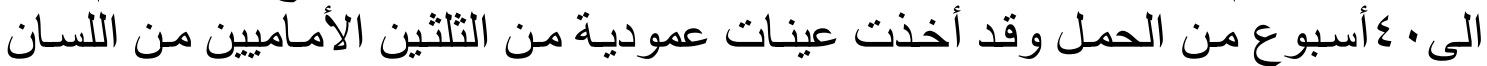

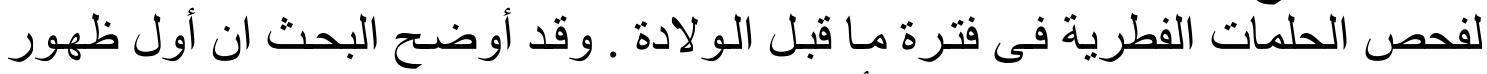

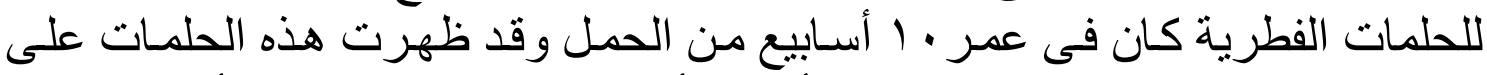

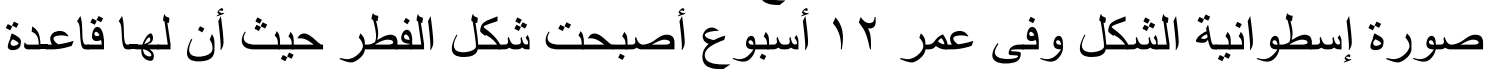

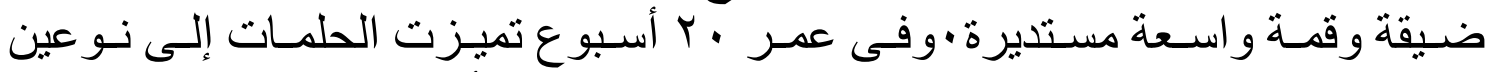

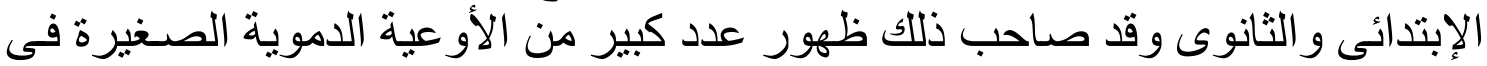

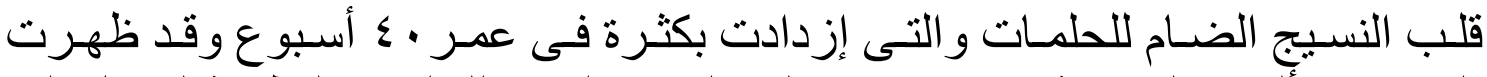

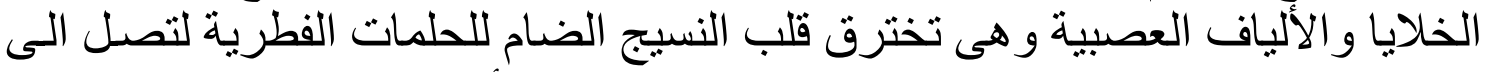
الغشاء الطلائى وقد صـاحب ذلك ظهور براعم التذوق الأوليـة و كانت على هيئة بقع موضعية فى الغشاء الطلائى للحلمات الفطرية و كانت تتكون من مجمو عة من الخلايبا

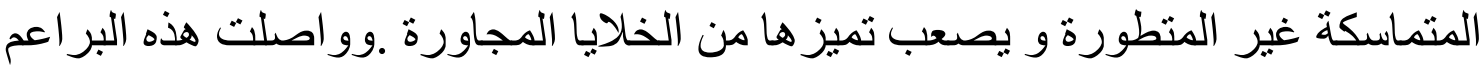

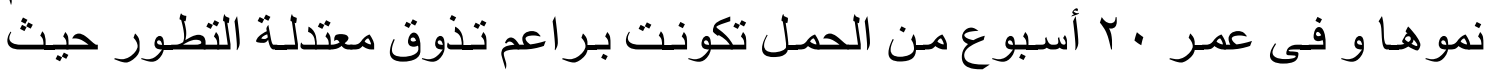
إزدادت خلاياها تطور ا.وقد إتخذت شكل بر اعم التذوق فـعر ، ع أسبوع من الحمل. 
Developmental and Histological Studies.......... 